\title{
The Emerging Pattern in Prostate Cancer in Zimbabwe
}

\author{
Article by Assam Musonza \\ Ph.D. in Clinical Research, Texila American University, Zimbabwe \\ E-mail: assammuso@yahoo.co.uk
}

\begin{abstract}
Background: Prostate cancer has become the leading cancer and cause of death in Zimbabwean men. The number of confirmed prostate cancer cases has been on the increase since the turn of the century. Considering this trend a retrospective cross sectional study was carried out to determine the pattern of the disease and the role played by the prostate specific antigen in its detection.

Objectives: The aim of the study was to determine the emerging pattern and the role of the prostate specific antigen in the detection of prostate cancer.

Methodology: A retrospective cross sectional study using secondary data was carried out. Prostate specific antigen results of 176 outpatients who visited a small medical facility in the Midlands Province of Zimbabwe were retrieved. Of these 26 proceeded to have biopsies done and the histology reports were retrieved and analyzed. The data was analyzed using Graph Pad Prism 6 software.

Results: $14.2 \%$ of the patients were confirmed by biopsy to have prostate cancer. Prostate specific antigen levels of greater than $20 \mathrm{ng} / \mathrm{ml}$ were associated with biopsy confirmed Prostate Cancer.

Conclusion: It was found out that Prostate Cancer is a major health problem in Zimbabwean men. Despite the low specificity of the prostate specific antigen, the test still plays a major role in the detection of prostate cancer. The age of those with confirmed Prostate Cancer is going down. There is need for improved health budget and public health education in Zimbabwe.
\end{abstract}

Keywords: Emerging pattern, prostate cancer, prostate specific antigen, retrospective cross sectional, Zimbabwe

\section{Introduction}

Prostate Cancer (PCa) also known as carcinoma of the prostate is the most common cancer among men only second to skin cancer in the world (Ferlay et al 2013)

\section{Epidemiology of PCa}

The incidence of PCa shows strong age, race and geographical dependence (Center et al 2012 and Babb 2014). There are very few cases of PCa in the less than 40 year age group (Fang et al 2001). PCa is less common in China, Japan and other Asian countries (Rebbeck 2013). There is higher prevalence in Scandinavian countries and the highest incidence and mortality in African-Americans (Nelson et al 2002). The high incidence in AfricanAmericans brings in genetic predisposition as a possible explanation for the high incidence in Africans as well.

The incidence rate of PCa in Africa is increasing at an alarming rate (Boyle and Levin 2008). PCa is the most commonly diagnosed cancer among men in Southern Africa and Western Africa including South Africa, Zimbabwe, Nigeria and Cameroon (Jemal et al 2012). The burden of cancer as a whole is on the increase in Africa due to the aging and growth of the population (Jemal et al 2012). This may be due to the increased prevalence of risk factors associated with life style changes including smoking, drinking, obesity, physical activity, reproductive behaviour and environmental pollution (Jemal et al 2012). 
Texila International Journal of Clinical Research

Volume 4, Issue 1, Dec 2016

In Zimbabwe, since 2004 PCa cases have increased by 104 per cent (Zimbabwe National Cancer Registry (ZNCR). An understanding of the pattern of the disease is required; who is affected, where they live and the age group most affected. The study was carried out to answer these questions.

\section{Screening tests for PCa}

The tests commonly used to screen for PCa are the Digital Rectal Examination (DRE) and Prostate Specific Antigen (PSA). In DRE, a doctor or nurse inserts a gloved, lubricated finger into the rectum to estimate the size of the prostate and feel for lumps. PSA tests measure the level of PSA in blood. PSA is a serine protease normally secreted by the prostate in large amounts into the seminal plasma but only tiny amounts enter the blood stream.

\section{Diagnostic tests for PCa}

A biopsy is the main tool for diagnosing PCa. Small pieces of tissue are removed from the prostate and examined under a microscope by a histopathologist to check for cancer cells. Another test for confirming PCa diagnosis is the PCA3 test (The prostate cancer gene3) performed in urine. A bone scan, computed tomography (CT or CAT) scan and Magnetic Resonance Imaging (MRI) can be used to find out if the cancer has spread.

The study used archival data from two of the procedures described above, firstly a screening test (PSA) and the biopsy as the confirmatory test. The main aim was to determine the emerging pattern of the disease and the role played by PSA in the detection of the disease.

\section{Methodology}

\section{Research design}

The research was a retrospective cross-sectional study. The design was selected because the data was available and could be obtained cost effectively. The data was obtained for diagnosis, not research, thereby excluding intentional bias. The main limitation with this type of study design was limited access to the facility for certain people. Certain demographic information was missing which could have added more data.

\section{Sampling technique}

A convenience type of sampling was employed where all the available data was retrieved.

\section{Data collection}

PSA test results and biopsy or prostatectomy histology reports were retrieved with all the required demographic details namely age and place of residence. No names were used and confidentiality was seriously guarded.

\section{Data analysis}

The Graph Pad Prism 6 software was used to analyse all the collected data. Correlation statistical method and T- Test was employed to compare PSA levels and PSA in various age groups against the standard reference range of $0-4 \mathrm{ng} / \mathrm{ml}$ to determine the most affected age group.

\section{Results}

A total of 176 PSA test results obtained between 2012 and 2016 were retrieved for analysis. The age range was from 27 to 91years of age. The mean age was 68. There were 112 cases with PSA levels of 0,20 to $4.0 \mathrm{ng} / \mathrm{ml}, 22$ cases of 4.1 to $10.0 \mathrm{ng} / \mathrm{ml}, 16$ cases of 10.1 to $20.0 \mathrm{ng} / \mathrm{ml}$ and 26 cases with levels of greater than $20.0 \mathrm{ng} / \mathrm{ml}$ (Fig 1). The mean PSA level was $9.05 \mathrm{ng} / \mathrm{ml}$. Those with PSA level greater than $4.0 \mathrm{ng} / \mathrm{ml}$; only 26 could be followed up with biopsy or prostatectomy histological reports (Fig 2). 
Texila International Journal of Clinical Research Volume 4, Issue 1, Dec 2016

Table 1: PSA Levels of confirmed Prostate Cancer patients

\begin{tabular}{|l|l|l|}
\hline Age & Location & PSA Level \\
\hline 65 & Urban & 21.28 \\
\hline 82 & Urban & 63.38 \\
\hline 80 & Rural & 32.05 \\
\hline 83 & Rural & 74.45 \\
\hline 81 & Urban & 36.00 \\
\hline 70 & Urban & 33.35 \\
\hline 80 & Rural & 20000 \\
\hline 73 & Rural & 30.18 \\
\hline 71 & Rural & 651.75 \\
\hline 88 & Urban & 105.22 \\
\hline 54 & Urban & 180.01 \\
\hline 69 & Rural & 28.30 \\
\hline 77 & Rural & 55.33 \\
\hline 73 & Urban & 100 \\
\hline 72 & Rural & 32.90 \\
\hline 71 & Urban & 38.27 \\
\hline 84 & Rural & 575.38 \\
\hline 67 & Urban & 862.07 \\
\hline 79 & Rural & 100 \\
\hline 81 & Urban & 24.58 \\
\hline 61 & Urban & 143.31 \\
\hline 82 & Urban & 73.29 \\
\hline 81 & Rural & 86.20 \\
\hline 88 & Urban & 63.91 \\
\hline 54 & Urban & 180.01 \\
\hline & & \\
\hline
\end{tabular}

Biospy confirmed Cancer cases

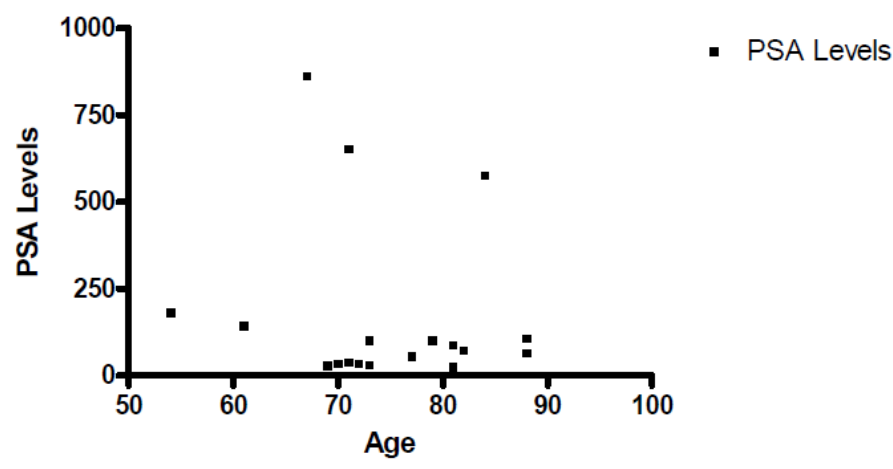

Fig 1. Biopsy confirmed Cancer cases

The 26 were all biopsy confirmed to have PCa. Their ages ranged from 54 to 88 years. The PSA levels ranged from 21.28 to $20000 \mathrm{ng} / \mathrm{ml}$ (Table 1).

The Gleason scores were seven to ten with $70 \%$ being poorly differentiated. Very high results greater than $100.0 \mathrm{ng} / \mathrm{ml}$ were excluded from the graphs. There was no significant difference in PSA levels of rural men compared to urban men (Table 1). 
Texila International Journal of Clinical Research

Volume 4, Issue 1, Dec 2016

PSA Levels VS Age in Zimbabwe

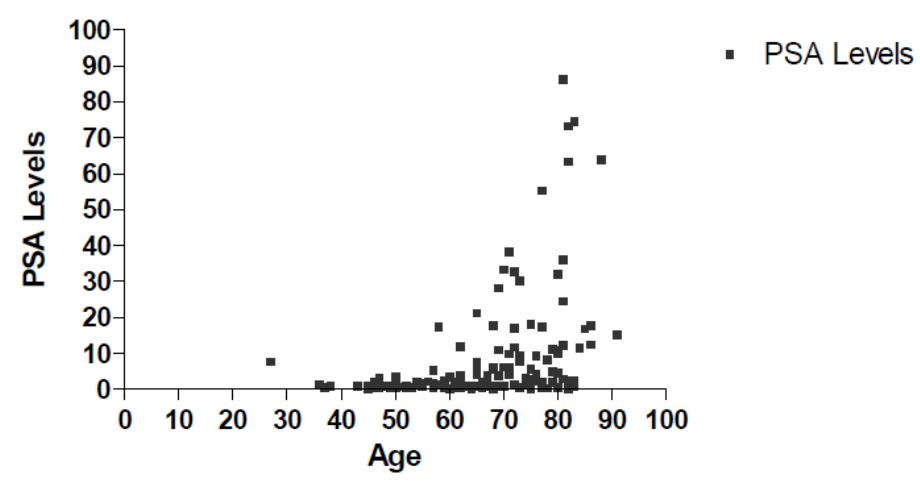

Fig 2. PSA levels vs Age in Zimbabwe

\section{Discussion}

The ZNCR reported a marked increase in PCa cases in Zimbabwe (ZNCR Report 2012). This study has confirmed that PCa is a major health problem with $14.2 \%$ of the patients screened with the PSA test having PCa. The pattern of high PCa cases is in agreement with incidence rates in African-Americans, where black men have a 1 in 5 lifetime probability of developing invasive PCa compared to 1 in 7 for whites (American Cancer Society 20092010).

The age range for those with biopsy confirmed PCa in the study is 54 to 88 years with a mean age of 74.64 years. This in agreement with other studies in Jos, Nigeria (Mandong et al 2000), Benin (Akang, Aligbe \& Olisa 1996) and Cameroon (Angwafo 1998).

There are raised PSA levels in the lower 40 to 50 years age group. The PSA levels greater than $20 \mathrm{ng} / \mathrm{ml}$ are associated with PCa. Although patients with PSA levels between 4 and 20 $\mathrm{ng} / \mathrm{ml}$ had no records of biopsy results due to various reasons alluded to above, it does not mean that there were no PCa cases in that group. It is possible that some practitioners could have adopted a wait and see attitude before subjecting the patients to the trauma of a biopsy.

Other studies have found PCa cases in the normal to moderately elevated PSA range of 4$20 \mathrm{ng} / \mathrm{ml}$ (Boyle and Levin 2008). Zimbabwe has limited resources and the PSA test is a valuable, cost effective tool for screening PCa. Despite its low specificity, PSA has a major role to play in the detection of PCa.

Four of the patients with very high PSA levels $(575,651$, 865and $>1000 \mathrm{ng} / \mathrm{ml})$ died within four to eight weeks of the diagnosis. This confirms the view that PCa patients in Africa present with late stage disease (Adeloye et al 2016). The other reports could not be retrieved due to them being unavailable due to various reasons.

The study highlighted that PCa is a major health problem in Zimbabwe. There is need for more comprehensive research into the aetiology and associated risk factors of the disease. Health education about PCa is essential to encourage men to understand the disease and avoid risky life styles.

The major limitation with the study was the difficulty in accessing biopsy records and even knowing whether further action was taken. Some patients never came back to check their results. There is still fear of invasive procedures due to traditional beliefs and ignorance. Cohort studies where follow-ups through all the stages of investigations and treatment can be monitored are recommended.

\section{Conclusion}

PCa is a major health problem for men over 50 years of age in Zimbabwe with a mean age of 74 years. The PSA test is playing a major screening role in the detection of PCa. An improved health budget is fundamental to meet the challenges presented by non- 
communicable diseases as a whole, PCa included. There is also need for improved public health education of the men to increase awareness of the threat of PCa to their health.

\section{References}

[1.] Adeloye, D., David, A.R., (.....) and Ayo, C. K (2016). An Estimate of the Incidence of Prostate Cancer in Africa: A Systematic Review and Meta- Analysis. PLos 1 O: 11(4):e0153496

[2.] Akang, E.E, Aligbe. J.U., Olisa, E. G (1996). Prostatic Tumours In Benin City in Nigeria. West Afr J M ed 15 pp 56- 60

[3.] American Cancer Society (2009 - 2010). Cancer facts and figures for Africans and Americans (2009-2010) American Cancer Society Atlanta GA (2009)

[4.] Angwafo. F. F (1998). Migration and prostate cancer: an International Perspective. J Natl Med Assoc 90 (11 suppl) S720 - S723

[5.] Babb, C., Urban, M., Kielkowsk, D., and Kellett, P. (2014). Prostate Cancer in South Africa: Pathology Based National Cancer Registry data (1986-2006) and Mortality rates (1997-2009). Prostate Cancer. Volume 2014, Article ID 419801.

[6.] Center, M. M., Jemal, A., Lortet-Tieulent, J., Ward, E., Ferlay, J., Brawley, O et al (2012). International variation in prostate cancer incidence and mortality rates. EurUrol, 61. 1079-1092.

[7.] Fang, J., Metter, E.J., Landis, P., Chan, D W., Morrell, C. H., Carter, H. B. (2001). Low levels of prostate specific antigen predict long term risk of prostate cancer: results from the Baltimore Longitudinal Study of Aging. Urology; 58, 411-416.

[8.] Ferlay, J., Steliarova-Foucher, E., Lortet-Tieulent, J., Rosso, S., Coebergh, J. W. W., Comber, H., Forman, D., Bray, F. (2013). Cancer incidence and mortality patterns in Europe: Estimates for 40 countries in 2012. Eur J Cancer 49, 1374-1403.

[9.] Jemal, A., Bray, F., Forman, D., O’Brien, M., Ferlay, J., Center, M., and Parkin, M.. (2012). Cancer Burden in Africa and Opportunities for Prevention. Cancer. DOI; 10. 1002/cncr. 27410, Received August 10 2011; Revised: October 24, 2011, Published online in Wiley online Library (wileyonlinelibrary.com).

[10.] Mandong. B., Iyap, Obekpa. P.O., Orkar. K.S (2000). Urological Tumours in JUTH: A Hospital based histopathological study. Nig. J. Surg Res 2 p108 - 112

[11.] Nelson, W. G and DeMarzo, A (2002). Focus on prostate cancer. Cancer Cell August 2002, Vol 2(2); 113-116 doi: 10. 1016/s1535-6108(02) 00103-4

[12.] Rebbeck, T. R., Devesa, S S., Chang, B. L., et al (2013). 'Global Patterns of Prostate Cancer Incidence, Aggressiveness, and Mortality in Men of African Descent,"’ Prostate Cancer, vol. 2013 Article ID 560 857, 12 pages, 2013. Doi: 10.1155/2013/560857

[13.] Zimbabwe National Cancer Registry Report 2012. 